\title{
The impact of globalization on regional marketing
}

\author{
Denisa Jánošová, ${ }^{1 *}$, Lenka Labudová ${ }^{2}$ \\ ${ }^{1}$ University of Ss. Cyril and Methodius in Trnava, Slovakia, The Faculty of Mass Media \\ Communication, Department of Marketing Communication \\ ${ }^{2}$ University of Ss. Cyril and Methodius in Trnava, Slovakia, The Faculty of Mass Media \\ Communication, Department of Marketing Communication
}

\begin{abstract}
The impact of economic globalization on regional development is a frequent topic of professional and public debate. Globalization has become a phenomenon that has a tremendous impact and knows no boundaries. Through its influence, it transformed the whole society and connected all the cultures of the world. It has provoked innumerable qualitative changes that have affected the world economy, world trade, transport, ecology and other important areas. Globalization can also be called a driving force for economic change through which it has accelerated areas such as information and communication technologies, innovation, new forms of competitiveness and other areas that have been able to support the mobility of global capital of the whole population. Globalization is a phenomenon that has legitimately included in humanity's most advanced history. With its coming, the whole world has gradually realized that our planet is becoming smaller and smaller. The main aim of our article is to identify and analyze indicators of the green city in the capital of Slovakia, Bratislava. Based on available data and critically evaluate the results of the analysis and formulate recommendations for self-government.. Regional development and improving the living conditions of the population are, in this period of time, very important topics. Attention is focused on the development of society and economic life, which is unevenly distributed and it is calling for the need of coordinating tools
\end{abstract}

\section{Introduction}

The environmental behavior of cities varies from city to city, but nowadays aware cities place increasing emphasis on the environmental management and administration of the city. Urban areas currently account for over $50 \%$ of the world's population, with cities accounting for 60 $80 \%$ of energy consumption and about the same share of carbon emissions. Rapid urbanization puts pressure on water supply, sewerage, public health, ecosystems. Establishing measures to create green cities can increase the quality of life in the cities. For example, strengthening the public transport system can reduce inequality by improving access to public services, increasing comfort and helping to reduce congestion. Cleaner fuel for transport and electricity generation can reduce local pollution and improve air quality to

\footnotetext{
*Corresponding author: denisa.janosova@ucm.sk, 2764922@student.ucm.sk
} 
increase the health of city / region citizens. The green spaces of the city also stimulate social interaction and improve human well-being and health. The article was divided into theoretical and analytical part. In theory, we focus on globalization, regional development and regional policy. Subsequently, we focus on the green economy of cities and the European Green City Index, specifically in the city - Bratislava and its strategic direction. In conclusion, we focus on recommendations for Bratislava in its future direction. The main aim of our article is to identify and analyze indicators of the green city in the capital of Slovakia, Bratislava. Based on available data and critically evaluate the results of the analysis and formulate recommendations for self-government.

\section{The development of worldwide globalisation and its aspects}

The development of the global economy in the last few years has undegone many changes, caused by globalisation and its effects. Globalisation has transformed society as a whole, connecting all cultures of the world, while simultaneously causing an immense number of qualitative changes, which impacted the global economy, global trade, transport, the environment, and other areas. Two of the most salient phenomena in the world economy in recent years have been a rapidincrease in the extent to which economies have become interconnected and a significant rise inincome inequality in many countries. [1] This phenomennon connected the entire world, creating a global structure to the economy. Economic globalisation is based on a liberalistic conception of the free market. In other words, it counts on the activity of self-regulating forces and on functioning on the basis of private ownership and business freedom. "Advances in information technology and transportation have dramatically expanded economic, political and cultural interaction between actors all over the place. This process, called globalization, is indeed not a new phenomenon, but its scale and pace has considerably increased since the 1980s driven by the internet revolution and major progress in transportation and logistics, namely containerized cargo and roll-on-roll-off cargo ships. These developments have led to dramatically falling transportation and communication costs and brought the world's markets and cultures closer together than ever" [2]

Economic and technological changes are the moving forces and simultaneously the results of globalisation. Throughout the entire world, there has been a growth of trade after global markets grew virtually closer through the use of communication technologies. "Innovations are a specific tool for entrepreneurs, a means by which changes are used as opportunities for doing business in a different area or for providing different services. "Entrepreneurs need to look for the sources of innovation purposefully, i.e., to search for the changes and their symptoms that signal the opportunity for successful innovations. "[3] The same technologies connect distant companies and allow them to move their activities into areas with lower expenses. The moving forces of economic globalisation are, first and foremost, the internationalisation of markets, with the simultaneous development of trade. "Innovations are a practical transfer of ideas into new products (products and services), processes, systems, and social relationships. "[4]

The basic preconditions of economic globalisation are the permeability of borders, the freedom of movement, the degrading of trade restrictions, the equalising of the income level of the populace, the growth of information on manufacturing and manufactured products and the application of new information technologies, the homogenization of markets, the access of a large number of smaller companies to globalized markets and the long-distance, realtime managing of marketing.

Among the positive impacts of globalisation, we can by all rights include:

- Investments by transnational companies help countries secure new jobs and the skills necessary for the jobs. 
- Transnatioal companies bring wealth and foreign currency to local economies when buying local resources, products and services - providing resources for education, healthcare and infrastructure.

- The unification of global economies provides huge potential for economically strong entities, for expansion into different parts of the world.

- While earlier, it might have been harder for many countries to enter global markets, globalisation provides poorer countries with the opportunity to utiliose the advantages of global trade [5] .

\section{Regional politics and regional development}

The term region has its own well-grounded place within the various scientific disciplines, but according to the opinion of many regionalists, the starting point for defining a region is its geographic significance. The definition of a region as a territorial unit, with economic, social, cultural and political attributes, is possibly one of the most fitting definitions of a region. This territorial unit develops and operates continuously and dynamically. Economists, on the other hand, have also started to devote substantial effort to constructing measures of globalization that extend well beyond the traditional concern with trade openness. [6]

Regional economists define a region as a "territorial-spatial unit, in which it is possible to define a socio-economic system and accurately delineate it within a space with the use of one or several attributes. Regional upgrading and downgrading need to be attentive to the role of labour in the tightening landscape of 'relative competitiveness' and the political economy of regional integration policies, foreign ownership and the global economic crisis. [7]We can delineate a region based on relations, by merging areas that have strong mutual spatial ties, or based on homogenity, by merging the homogenous area according to selected attributes or based on functionality. The socio-economic system is not located in an abstract space, but is delineated within a specific environment, with which it is in mutual interaction." [8]

\subsection{Regional politics}

Practice and knowledge from the field of science focused on researching regions has long since pointed towards the necessity of perceiving regions as richly structured subsystems, that are part of a greater whole, of a state. The growth of individual regions is therefore a very important and inseparable part of the system, a part which participates within the system in the growth and development of the entire national economy of a state. The concept of uneven and combined development (U\&CD) interprets dynamic historical change and comparative geographical differentiation in terms of the co-existence of tendencies towards differentiation and equalization of the conditions of production, consumption, distribution and exchange, deriving from capital accumulation and political multiplicity. [9] The region is a certain form of separate organisational unit, composed of mutually interconnected and mutually interacting relations, which influence its existence and its further evolution. Regional politics pay great attention to supporting the development of all regions. Every state has their regional politics and policies oriented at solving the issue of regional disparities, by utilising various means for managing economic processes. The primary goal of every state is to achieve a balanced status in the socio-economic development of its subsystems, i.e. of its regions. The world willmove towards more plurilateral agreements, among "coalitions of the willing. [10]

Regional politics are primarily focused on the creation of prerequisites for the rational utilisation of resources in the individual regions based on need, and are subsequently focused on the creation of ideal conditions for the reception and realisation of measures related to the 
socio-economic functions of the regions. Economic globalisation has occurred since the turn of the Millennium [11] Through their organisations, regional politics provide a balanced economic and social development in the regions and simultaneously provide protection of the natural environment and strive for environmental balanace. Some of the main values of regional politics include regional competitiveness, equality, national economic growth, political, social and economic stability. The large country fosters industrial agglomeration (geographical concentration) in the early stage of globalization, but loses manufacturing in the later stage of globalization.[12] Based on this, we can state that regional politics are focused on reaching economic goals, but their primary goal is achieving social cohesion, as well as generating jobs. Politics focused on securing the developmental goals of all regions increase the competitiveness of regions through supporting innovations and more effective use of resources.

\subsection{Regional development}

"Monitoring the development of the global economy, as well as that of the individual national economices, points to the effect of significant dynamic processes in this area. One of the significant accelerators of these processes is globalisation, which also brings with itself changes to the socio-economic environment. In accordance with ever more intensive globalisation processes in the global economy, it is possible to focus on reflecting about economic growth and development of the individual continents, or their parts, or in turn, within the context of a single economy, to identify, analyse, interpret and suggest solutions that would lead to the removal of existing regional disparities."[13]

"Globalisation and integration of global economy influence the development of both global and lower-positioned hierarchical levels, the lower ones including the state, regional and local level. In the context of these dynamic processes, a change in the outlook on the significance and role of not only nation states, but especially lower-tier administrative units, i.e. regions, is coming to the forefront." Concerning this, K. Skokan emphasises the growing significance of regions in the area of economic development of the national economies. It is exactly the regions that Skokan considers to be significant economic units, in which the economic life of a society concentrates."[14]

Regional development is very complex, a complex process that incorporates the following phenomenna, which mutually influence each other: Multifold interconnectedness of all entities of regional development. Behaviour, actions and activities of the individual entities that work in the area of regional development. Mutual interaction between all entities and mechanisms occurs on all hierarchical levels within the process of development. With the massive economic development and vast environmental degradation over the last decade, "sustainability" and "sustainable development" have become primary concepts in governments "eagenda[15].This includes the influence of strong mechanisms, that are often times hard to predict and also have unpredictable consequences. Current views on regional development stress the effects of spontaneous processes and their management through regulatory mechanisms. It is precisely in this context that the area of regional development is being searched for answers to, how and to what extent can spontaneously generated processes influence an important change.[16]

\section{The green economy of cities}

Currently, more than half of the world population lives in cities. It is expected that by 2050 , this number will increase to as high as 68 percent. Migration from rural areas to urban areas, especially in Africa and Asia, is caused by poverty and related socio-economic factors. [17]To a large extent, the quick expansion of cities is carried out without any urban planning 
strategy and the subsequent human pressure has very detrimental effects on woodlands and whole landscapes, as well as on green spaces in cities and their surroundings. Environmental effects of urbanization are often worsened by climate change and include the increase of pollution, the decreased availability of food and resources, as well as increased poverty and an increased frequency of extreme climate events. [18]

Since the urban population grows and the consequences of climate change worsen, our cities are in need of adapting. It is time to invest in effectiveness and renewable energy, revitalise cities, rural municipalities and states. A very good move for cities is the transition to a cleaner, healthier and economically more viable future through the improvement of effectivity, investments into renewable energy technologies and legislative reforms. [19]

Cities are motors of future growth, offering their inhabitants greater opportunities in education, employment and prosperity. Despite this, their growth could also cause negative consequences, such as overburdening of transport, informal settlement, the expansion of cities, environmental pollution, non-effective use of resources and climate change. Effective and intelligent technologies can offer answers to many of these challenges for urban spaces. [20]

The essence of green growth is support of economic growth, and simultaneously, ensuring that natural assets could continue to provide resources and environmental services, on which all our prosperity is founded. The society of the 21 st Century has to face many economic confrontations ;e.g. between the supporters of financially demanding environmental protection measures and wealth and power held by multi-national and even global corporations seeking the highest possible profits. [21] To achieve this essence, or this goal, it is necessary to simulate the further development of innovations and investments, for the support of sustainable growth, and the creation of new economic opportunities. In the present, the criteria of the natural environment's quality and the real exhaustibility of natural resource deposits represent equal conditions for the achieving of economic growth. [22]

\subsection{European Green City Index}

While the last 20 years have seen great progress in bridging political and economic differences between eastern and western Europe, one significant difference remains in the area of the environment. Thirteen of the best fifteen European indices are located in western Europe; eleven of the fifteen lowest-rated European indices are part of the former eastern block. Eastern cities had so far focused on the consequences of earlier neglect of the environment during the communist era.

For each city, an overall index ladder is compiled, and an independent succession order for each of the individual categories. The results are presented numerically (for European, American and Canadian indices) or in five performance ranges, from "considerably above average" all the way to "considerably below average" (for Asian, Latin American and African indices). [23]

The European Green City Index takes into consideration 30 individual indicators per city, which cover a wide range of areas related to the natural environment and positions cities based on transparent, consistent and replicable rating. The relative score assigned to individual cities (for their performance in specific categories, as well as generally) is also unique to the index and allows for direct comparison between cities. The index involves 8 basic areas to which the specific quantitative and quality indicators pertain to. These areas include $\mathrm{CO}_{2}$ emissions, Energy, Buildings, Transport, Water, Waste and soil usage, Air quality and the Management of the natural environment. [24] 


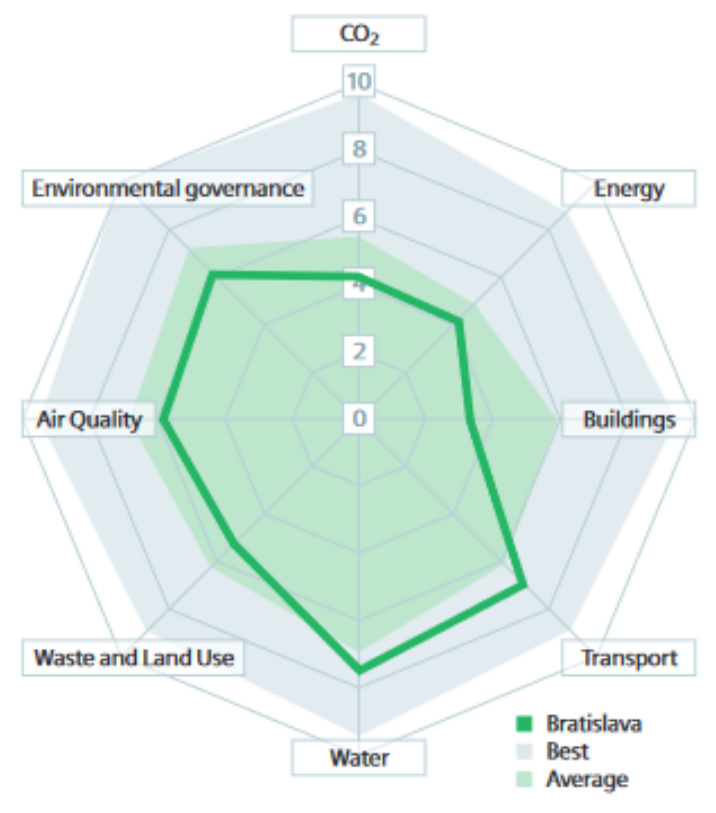

Fig. 1. Position of Bratislava in basic areas of the European Green City Index

\subsubsection{Bratislava and the European Green City Index - Analysis}

As the capital and largest city in Slovakia, Bratislava is the centre of economic, financial, cultural and political activity. The city's trade activity is oriented mainly towards the service sector, though the city is also home to several important industrial companies. Within the European Green City Index, Bratislava positioned itself in the 20th place, the city's score being 56,09 out of 100 .

- $\mathrm{CO}_{2}$ emissions: Bratislava held the 21st place for carbon dioxide emissions. The main sources of these emissions are the local chemical industry, energy supplying and transport.

- Energy: In the energy-rating area, Bratislava positioned itself in 21st place. However, in Bratislava, all energy is produced only from non-renewable sources.

- Buildings: In the rating of buildings, Bratislava earned the 23rd place. The capital city has a large number of buildings built 60 years ago, many of these built in the communist era, when only little attention was payed to energy-saving effectiveness.

- Transport: In the area of transport, Bratislava achieved the best total result from all the surveyed areas, coming in 8th place. The highest proportion of people using mass transit in Bratislava are those who commute to work (70\%, compared to the average of $42 \%$ ).

- Water: In the area of water management, Bratislava positioned itself in 14th place, achieving good results, particularly with sectional indicators.

- Waste and soil usage: Bratislava positioned itself in this area in 21st place. Policies of decreasing the amount of waste and the production of waste were particularly well-rated. 
- Air quality: Bratislava stood in 21st place in the area of air quality. The current strategy of the city is the gradual solution of the existing problems, e.g. through cooperation with the main producers of emissions, as a first step towards the overall improvement of air quality.

- Management of the natural environment: Bratislava was rated in 20th place in the area of natural environment management. This partly reflects the general lack of awareness of citizens and politicians about environmental aspects. [25]

Table 1. Position of Bratislava in the European Green City Index

\begin{tabular}{|c|c|c|}
\hline \multicolumn{3}{|c|}{ OVERALL } \\
\hline ORDER & CITY & SCORE \\
\hline 1 & Copenhagen & 87,31 \\
\hline 2 & Stockholm & 86,65 \\
\hline 3 & Oslo & 83,98 \\
\hline 4 & Vienna & 83,34 \\
\hline 5 & Amsterdam & 83,03 \\
\hline 6 & Zurich & 82,31 \\
\hline 7 & Helsinki & 79,29 \\
\hline 8 & Berlin & 79,01 \\
\hline 9 & Brussels & 78,01 \\
\hline 10 & Paris & 73,21 \\
\hline 11 & London & 71,56 \\
\hline 12 & Madrid & 67,08 \\
\hline 13 & Vilnius & 62,77 \\
\hline 14 & Rome & 62,58 \\
\hline 15 & Riga & 59,57 \\
\hline 16 & Warsaw & 59,04 \\
\hline 17 & Budapest & 57,55 \\
\hline 18 & Lisbon & 57,25 \\
\hline 19 & Ljubljana & 56,39 \\
\hline 20 & Bratislava & 56,09 \\
\hline 21 & Dublin & 53,98 \\
\hline 22 & Athens & 53,09 \\
\hline 23 & Tallinn & 52,98 \\
\hline 24 & Prague & 49,78 \\
\hline 25 & Istanbul & 45,2 \\
\hline 26 & Zagreb & 42,36 \\
\hline 27 & Belgrade & 40,03 \\
\hline 28 & Bucharest & 39,14 \\
\hline 29 & Sofia & 36,85 \\
\hline 30 & Kiev & 32,33 \\
\hline
\end{tabular}

\subsubsection{The strategic development of Bratislava}

Air quality - The city of Bratislava issues certificates and permissions for building construction and the opening of completed buildings. These are mainly small sources of pollution, such as sources of a thermal and technological nature. Simultaneously, in this 
particular area, the city also issues sanctions and collects fines for air pollution. [63] Just like the other regional cities of the country, the capital city has also prepared a strategy in the area of improving air quality in the city, as well as in the area of climate change.

Energy - The electric energy distribution for the capital city within its territory is supplied by several sources of electric energy, more specifically, three types of powerplants - a thermal, company-operated and hydroelectric powerplant. A lingering problem of the city are the high energy demands of the buildings and the administration throughout the whole city, as well as a low percentage of energy produced from renewable resources.

Transport - Transport in the city of Bratislava consists of a complex system, with municipal mass transit provided by buses, trams (streetcars) and trolleybuses. The overburdened state of the roads in the capital is constantly intensifying, as part of the growth of motorisation, leading to the overburdening of roads and creation of everyday traffic jams. To resolve the transport situation and the management of transport in the city, the city authorities had created a strategic document - a Concise plan for urban transport.

Waste - In the area of waste management, the city had developed the Waste management programme, tasked with the management of this area. The long-term goal of the city is to decrease the amount of stored waste and simultaneously increase its reusability, e.g. for heat production or electric energy production. Another key goal is to increase the amount of separated waste and the collection of recyclable waste. The main problem of the city in this area, predominantly, are the insufficient capacities for disposing of the growing number of waste.

Water - One of the shortcomings of the city's water management network is the fact that the city currently does not have a developed strategic document aimed at resolving the issues of the city's water network. Despite this, the city is continuously strengthening its policy with regards to water resources and is trying to, above all, utilise them rationally. Simultaneously, the city is increasing its capacities for providing good-quality water, from both the available as well as new sources of water.

City greenery - Currently, the city does not have a document at its disposal, which it could use as a guideline in the area of natural environment and management and maintenance of city greenery. The city is currently beset by issues of drying up greenery, especially trees, which start to dry out mainly due to hot summer days. The city's municipal government is actively working on decreasing the consequences of this problem, and is trying to foster the new planting and better maintenance of green spaces and tree-lined streets. [16]

\section{Conclusion}

It is exactly cities and regions that are the centres of economic development and high population concentration. Throughout the world, politicians and government representatives jointly attempt to, more or less successfully, arrange mutual obligations and specific steps leading to the reduction of climate change, as well as readiness for its impacts $[26,27]$. The role which cities themselves will play in this will be no doubt decisive.

Bratislava shouldn't be an exception, quite the contrary. The city should search for and implement new solutions in order to position itself among those European cities, that have already set off on the right path. We should start thinking about the long-term impacts of our activities on our city and the landscape that surrounds it. Interventions into the landscape caused by the development of cities must not lead to the definitive disfiguring or indelible damage to these permanent landscape values.

If Bratislava, as well as other cities, is to be a functional, refreshing place for its inhabitants and visitors, it must be ready to deal with the expected global and local negative impacts on the natural environment. Let us therefore build Bratislava meaningfully, as a resistant, decent and safe place. 
It is necessary to develop the natural environment of the city from several perspectives, including from an environmental, economic and social perspective. In the case of the natural environment, the economic perspective should never be in first place. Investments into the development of the natural environment never represent its entire value to the future, as the value will see a multifold return [28]. It is necessary to approach the environmental or social perspective depending on the intensity of the function, that a specific solution is meant to fulfill.

We need to suggest solutions that bring a city financial savings, especially from a longterm perspective. And vice versa, we need to perceive financial investments as justified in places, where the intensiveness of a solution's use is high and maintenance difficult. Besides a physical form, social qualities also have a non-physical form.

In Slovakia, the institutional infrastructure for regional development is already forming and experiences with strategic planning are spreading. Strategic planning is an important pillar of regional and urban marketing. However, for the time being, the main effort is concentrated on the usage of European resources, seen as the only route towards resolving the issues and kickstarting development. This is why, even in the near future, regional development will still be decided mainly by strategies formed at the above-regional level. Only gradually, assuming a growth in economic performance and regional awareness, could conceptual approaches originating directly from the regions be strengthened.

This paper is an output of the research project supported by the Grant Agency of the Ministry of Education of the Slovak Republic and the Slovak Academy of Sciences (VEGA) No. 1/0078/18 titled Aspects of Marketing Communication in the Management Processes of Circular Economy.

\section{References}

1. Antras, P., De Gortari, A. and Itskhoki, O. Globalization, ineaquality and welfare. Journal of International Economics 108, 387-412 (2017)

2. G. Pehnelt, Glob. and Inflation in OECD c., available at: https://ideas.repec.org/p/jrp/jrpwrp/2007-055.html (2007)

3. Z. Dytrt, M. Striteská, Efekt. in., odpv. v man., 240, (2009)

4. M. Gregor, B. Mičieta, Produktivita a in., 216, (2010)

5. J. Hipš, P. Ďurišová, Svet je len jeden, Príručka glob. rozvoj. vzd., 24, 5-7 (2006)

6. Duernecker, G. and Vega-Redondo, F. Social networks and the process of globalization. Review of Economic Studies, 85, No. 3, 1716-1751 (2018)

7. Smith, A., Pickles, J., Bucek, M., Pastor, R. and Begg, B. The political Economy of Global Production Networks: Regional Industrial Change and Differential Upgrading in the East European Clothing Industry. Journal of Economic geography, 14, No. 6, 1023-1051 (2014)

8. J. Hančlová, L. Tvrdý, Modelováni klas. reg. t.p., 150, (2004)

9. Dunford, M. andLiu, W. (2017). Uneven and combined development. Regional studies, 51, No. 1, 69-85 (2017)

10. Stiglitz, J. E. (2018). Trump and Globalization. Journal of Policy Modeling 40, No. 3, 515-528 (2018)

11. Horner, R., Schindler, S., Haberly, D. et al. Globalisation, uneven development and the North-South 'big switch'. Cambridge Journal of Regions Economy and society, 11, 17 $33(2018)$

12. Kato, H. and Okubo, T. Market size in globalization. Journal of International Economics 111, 34-60 (2018) 
13. I. Nedomlelová, Selected models of e.g.v.t., 258 (2007)

14. K. Skokan, Konkurenceschopnost, inovace a kl. v reg. rozvoji, 6 (2004)

15. Akan, M. O. A. and Selam, A. A. Assessment of Social Sustainability Using Social Society Index: A Clustering Application. European Journal of Sustainable Development 7 No. 1, 412-422 (2018)

16. P. Čajka, L. Rýsová, Reg. rozvoj a reg. politika v k.p.s, 10, (2008)

17. Wright, S., Nelson, J.D., Cooper, J.M. and Murphy, S. An evaluation of the transport to employment (T2E) scheme in Highland Scotland using social return on investment (SROI). Journal of Transport Geography 17, 457-467 (2009)

18. The green city, Building greener cities, available at: http://thegreencity.com/

19. Green cities, Get your city to go green, available at: https://www.earthday.org/campaigns/green-cities/

20. Economist intelligence unit, The green city index, available at: https://eiuperspectives.economist.com/sustainability/european-green-city-index

21. Radošínska, J. and Višňovský, J. Transformations of Public Sphere in the Era of Digital Meda. European Journal of Science and Theology 12, no. 5 85-96 (2016)

22. T. Guštafíková a kol., Vybrané indikátory zeleného rastu v SR, 50, 2014

23. World resources institute, What is a g.e., available at: https://www.wri.org/blog/2011/04/qa-what-green-economy-

24. Siemens, European green city index, available at: https://www.siemens.com/press/pool/de/events/corporate/2009-12-

Cop15/European_Green_City_Index.pdf

25. Bratislava, available at: https://bratislava.sk/

26. M. Nadanyiova, E. Kicova, M. Rypakova, Green marketing and its exploitation in Slovak companies. In 4th World Conference on Business, Economics and Management (WCBEM) (Ephesus, Turkey, 219-226, 2015)

27. H. Palus, H. Matova, A. Krizanova, J. Parobek, A survey of awareness of forest certification schemes labels on wood and paper products. Acta facultatis xylologiae 56, $1,129-138$ (2014)

28. W. Sroka, R. Szanto, Corporate Social Responsibility and Business Ethics in Controversial Sectors: Analysis of Research Results. Journal of Entrepreneurship Management and Innovation 14, 3, 111-126 (2018) 